\title{
Perceptions of Integrated Experiential Learning of Graduate Marketing Students
}

\author{
Raghava Rao Gundala \\ University of Wisconsin-Stout \\ Arthur Lok Jack Graduate School of Business \\ gundalar@uwstout.edu \\ Mandeep Singh \\ Western Illinois University \\ T. Kathleen Cochran \\ University of Wisconsin-Stout
}

\begin{abstract}
Experiential learning projects have become a mainstay of a multitude of undergraduate business courses as they allow students to apply theoretical knowledge to real-world issues. At the graduate level, the use of case studies is a primary teaching method, but one cannot fail to notice an increase in the interest and use of experiential learning projects and assignments. As more emphasis is placed on the practical application of theory across the marketing curricula, buttressed by accrediting agencies, the need for incorporating these experiential learning projects has become an integral part of many university curricula at both graduate and undergraduate levels.

While the inclusion of these projects has been in practice for some time, the ideal addition to these experiential elements is restricted to a single course. This study examines the impact of including an experiential learning project that was framed across two graduate courses for an individual client. This study adds to the existing knowledge by using a unique integrative approach, across two separate graduate marketing courses, providing students with a progressive real-world experience over an extended period of consulting interaction and time. Student perceptions associated with the efficacy of this extended experiential learning exercise are also furnished.
\end{abstract}

Keywords: Client projects, service learning, experiential learning, graduate marketing courses, business school.

\section{Introduction}

The Association to Advance Collegiate Schools of Business (AACSB, 2013), in their accreditation standards, articulated the need for management schools to engage with the community. These standards also highlight the need for creative and innovative student projects that engage and deepen student understanding of the course content. The intent is to strengthen student value for potential employers with specific skills that enable them to make early contributions.

In tune with the new AACSB standards, Hart and Mrad (2013) said, that gaining practical experience by working with and in businesses before graduation is also necessary for graduatelevel business students. Companies now want their new employees to "hit the ground running," 
challenging business schools to develop keen critical thinking, problem-solving and professional communication skills in the students before graduation.

Critical thinking and communication skills can be developed successfully by using experiential learning projects. These experiential learning projects are an ideal way to bridge the gap between student learning in the classroom and employer expectations on the job (Clark and White, 2010; Maskulka, Stout, and Massad, 2011).

\section{Literature Review}

Traditionally, academicians have relied on the lecture method of teaching with the instructor as the central figure in transferring information to foster student learning (Kennedy, Lawton, \& Walker, 2001). However, the lecture method is often criticized for not stimulating critical thinking and communication skills necessary for students to be successful in businesses upon graduation (Munoz \& Huser, 2008). An increasingly popular alternative to the traditional lecture method of instruction is experiential learning (Warren, 2012). This same philosophy has been captured in the metaphor that a faculty member needs to transform himself or herself from "being a sage on the stage to a guide on the side;" that is, to become a creative facilitator and an instrument that aids learning and self-discovery.

Keeton and Tate (1978) described experiential learning as an educational opportunity in which the learner is in direct contact with the studied realities. However, Kolb (1984) defined experiential learning as "a process whereby knowledge is created through the transformation of experience." Kolb also said that experiential learning must include a concrete experience, reflective observation, abstract conceptualization and active experimentation. Most importantly, the learner must be involved in all these activities, for then and only then, the activity should be called an experiential learning activity.

Further, researchers identified several critical components needed in experiential learning, such as, interaction among the students, company personnel, faculty and, most importantly, keeping students in contact with the real-world scenario (Gentry, 1990). Experiential learning involves students with the experience and later, reflecting on the experience to draw conclusions based on their experiences that will and can be applied in the future to improve their performance (Frontczak \& Kelley, 2000). Lecture-based classes promote passive learning (Kennedy et al., 2001), and leave students little time for reflection (Civi \& Persinger, 2011). Experiential learning helps foster critical thinking and problem-solving skills (Kennedy et al., 2001) and positively impacts student learning (Warren, 2012).

There is a broad-based consensus in the efficacy of experiential learning practices. Several researchers have found experiential learning techniques to be effective in teaching in the marketing discipline (Bridges, 1999; Drafke, Schoenbachler, \& Gordon 1996; Gruca, 2000; Hamer, 2000; Petkus, 2000; Speckt, 1985). These researchers recommended the use of experiential marketing projects as these learning experiences resulted in higher student engagement, improved understanding, and superior information retention.

Previous researchers proposed the use of many experiential learning strategies in the marketing curriculum (Bridges, 1999; de los Santos \& Jensen, 1985; Graeff, 1997; O'Hara \& Shaffer, 1995; Wynd, 1989). A more recent experiential learning technique has been to assign real company projects to students (Roth \& Smith, 2009). A real company project enables students to work with organizations and solve real business problems. 
Richardson and Raveed (1980) and de los Santos and Jensen (1985) mentioned that real company projects provide a conduit between theory and practice. Real company projects help students integrate the material taught in the classroom and ensure continuity (Gremler, Hoffman, Keaveney, \& Wright, 2000; Humphreys, 1981; Razzouk, Seitz, \& Rizkallah, 2003). Bridges (1999) suggested that incorporating real company projects into the curriculum has the added benefit of providing consistency in the students' view about the discipline of marketing because these projects are interactive, real world, and creative.

Craciun and Corrigan (2010) stated that graduates without prior work experience or who are not involved in experiential learning might face challenges as the marketing managers expect their recruits to think holistically to develop solutions to real-life problems. To help prepare graduates, many academicians teaching marketing embraced an integrative approach by including real company projects (Bobbitt, Inks, Kemp and Mayo, 2000; Darian and Coopersmith, 2001; Elam and Spotts, 2004, Munoz and Huser, 2008). These projects help graduates apply and refine skills and concepts learned in different marketing courses, compelling them to develop holistic solutions (McCarthy, 2010). Students feel a sense of accomplishment through experiential learning providing them the opportunity to integrate all they have learned and put it into action (Hagan, 2012).

Marketing is a discipline where the use of experiential learning methods is both applicable and advisable. Marketing is taught in a classroom where students need to understand customer needs/wants/desires as a process and then develop marketing plans that allow required satisfaction while achieving the company's objectives. This marketing plan involves analyzing the market and the competition, developing strategies and optimizing the elements of the marketing mix. Therefore, it becomes necessary for students of marketing to understand the many functions of a marketing manager - gathering information, evaluating alternatives and decide the best option to deliver superior customer value (Camarero, Rodriguez and San José, 2009). The use of experiential learning projects across business courses in general and marketing courses is extensive. Researchers have used experiential learning in a multitude of marketing courses. For example, O’Hara and Shaffer (1995) used experiential learning in personal selling and purchasing courses. Bobbitt et al. (2000) used experiential learning in marketing principles, personal selling, and sales management courses successfully. Students of these three courses practiced application of the concepts and develop skills discussed throughout the courses and evaluated the project as an enjoyable exercise, adding to their ability to learn and use the theoretical material. Further, there is a widespread consensus about the many benefits of incorporating experiential learning in teaching undergraduate and graduate marketing research courses.

While experiential learning projects have widespread adoption at the undergraduate level, the same is not so at the graduate level. Lack of popularity in these experiential learning projects in graduate courses can be ascribed to the attributes of the student population. In graduate courses, a higher percentage of students are adult learners. These adult learners have full-time jobs, family, and other responsibilities. These adult learners have a pressing need to achieve a school-work-life balance. Students also have varied backgrounds and experiences and may live far from the college campus, making it difficult to come together to work on team projects (Hagan, 2012).

\section{Research Contribution and Differentiation}

Research conducted in the past has mainly explored the use of real company projects in undergraduate courses with a limited examination of their use in graduate-level courses. This

Journal of the Scholarship of Teaching and Learning, Vol. 18, No. 2, June 2018.

josotl.indiana.edu 
research study contributes to the literature by examining the impact of incorporating an integrative experiential learning project across two graduate-level marketing courses for a single client.

The study attempts to identify student perceptions associated with the impact of an experiential learning project on their learning during this extended learning opportunity. The primary objectives of this research study are to measure student perceptions on (1) their motivation to learn; (2) a real company project as a useful learning pedagogy; (3) the real company project's contribution to developing knowledge and skills in the subject area; (4) the personal benefits gained from the actual company project; and (5) the overall assessment of the real company project.

\section{Project Description}

Current literature that examines the impact of experiential learning over multiple courses is rare. The authors found only two studies that evaluated the effect of experiential learning over multiple course offerings. The first study by Bobbitt et al. (2000) introduced the idea of integrating three marketing courses around a typical class project. They combined Principles of Marketing, Principles of Selling, and Sales Management classes. One group of students in the Principles of Marketing course created ideas for new goods and services. Another group of students from Principles of Selling class created a mock trade show, and students in the Sales Management class chose a product and created a role-play sales call from the mock trade show. Students in all three courses enjoyed applying the concepts and skills discussed throughout the courses. This approach to curriculum integration provided students with a "hands-on" opportunity to use marketing concepts and linked the critical component of realism, which is possible only through working with a real company. Another such study by Elam and Spotts (2004) integrated marketing management, campaign planning and management, and desktop publishing courses together and invited a real company to take part. This research is based on the same premise. Specifically, this study examines the impact of an integrative experiential learning project across two graduate courses in working in collaboration with an individual client.

\section{Project Organization}

\section{Phase I}

In phase 1 of the project, students enrolled in the (1) Customer Centric Innovation, or (2) New Product Development course were required to develop a new product by collaborating with their respective client. This was a collaborative effort, and the intent was to help develop logical new product offerings for each of the clients.

1. Graduate students enrolled in the Customer Centric Innovation course worked in teams of five to develop a "Business Plan Team Project to develop a new product or service" based on the guidelines provided in the textbook Developing New Products and Services, Sanders (2012).

2. Graduate students enrolled in the New Product Development course used a "Four-phase integrated new product development (iNPD) process" based on the textbook Creating Breakthrough Products by Cagan and Vogel (2013).

Journal of the Scholarship of Teaching and Learning, Vol. 18, No. 2, June 2018. 
At the end of the semester, student teams presented their ideas to the clients. The clients evaluated the student projects and, based on the feasibility of the ideas presented; they selected new products suitable for a potential launch.

\section{Phase II}

After the completion of the two matched courses, the students were channeled into a course on (3) Contemporary Issues in International Marketing, a required course for graduation.

In this course, the same student groups who had developed new product offering for their clients were required to create marketing plans to launch the products in international markets that had the most significant potential. To formalize this phase, students used "Country Notebook" to develop Marketing Plan based on the textbook "International Marketing” by Cateora et al. (2012).

\section{Project Method}

At the start of the semester, the faculty member presented the scope and nature of the experiential learning project to the student groups. Clients visited the classroom and submitted briefs about the company, discussed the organizational issues, business goals, and objectives.

After some work within their group, the student teams presented an initial proposal to the client for approval. The intent was to include and involve the client from the start of the project. This compelled students to be accountable and deliver professional reports to external constituents early in the process. Students were given a multitude of resources, including templates, and content outlines whenever applicable. This strategy of having the clients interact with the student from early on also helped formulate and align client expectations with the directions taken by the students, resulting in increased client and student satisfaction levels (Kunkel 2002). Clients were encouraged to provide feedback, suggest and recommend changes depending on their business needs. Students were required to incorporate this feedback and make all reasonable changes as indicated by the client and present a changed plan for the client's approval. Client visits were also integrated into the course to provide students with firsthand knowledge of their client's operations. This provided the students with a keen understanding of the client's processes and offered valuable insight into a professional work environment.

As the semester progressed, students collected required data and prepared formal written reports. Throughout the semester, the faculty and students met during the regular class time for lectures, case studies, and discussions covering the course content to deliver on the stated overall course objectives. Besides these subject related discussions, student groups were also required to provide their fellow students with two briefs, updating the entire class on the fundamental aspects of their experiential projects. Students were encouraged to work with each another, share insights, and use the class community to improve their overall effort.

At the end of the semester, student groups presented their findings and recommended actions in a verbal presentation and final written report to their peers, company executives, the instructor, and the business school faculty.

\section{Feedback to Student}

Besides the regular feedback to the students during the entire experiential project, the instructor provided verbal and written feedback three times to the students on the experiential project. The 
experiential project grade was a significant (35\%) of the overall course grade. The teams also received nongraded feedback from their respective clients at the end of the project. This closed the feedback loop and was considered most valuable and well received by students.

Clients were asked to provide feedback to the students and faculty members only after they had reviewed the final projects. The feedback received from the client consisted of a written summary of comments that were shared with the students. Mostly, this feedback was positive, complimenting the student's work and appreciative of the multitude of creative approaches. The business clients were complimentary of the fresh vantage point provided by the students. Many clients reported incorporating the relevant elements of the student proposals in their company's marketing strategies and plans.

\section{Data Collection and Analysis}

Graduate students enrolled in the three marketing courses, namely (1) Customer Centric Innovation; (2) New Product Development and (3) Contemporary Issues in International Marketing, being taught by the same professor, was asked to take part in this study. Of the 86 total students, 33 students completed the survey, resulting in a $38.4 \%$ response rate.

\section{Instrument}

The survey questionnaire was developed based on work of Parsons and Lepkowska-White (2009) and consisted of 19 items across four scales: Student Motivation to Learn, Project as a Learning Device, Skills, and Personal Benefits, and Overall 'Real Company Project' Assessment. The Student Motivation to Learn scale consisted of four items, with internal consistency reliability of.59. Because of a below acceptable item-total correlation (.05) (Field, 2013), the item "I prefer this to an all lecture course" was dropped from the scale. The resulting three-item scale had internal consistency reliability of 0.81 . The Project as a Learning Device scale was comprised of 4-items and had internal consistency reliability of 0.95 . The Skills and Personal Benefits scale had internal consistency reliability of 0.91 and consisted of 7-items. The Overall 'Real Company Project' Assessment scale had 5-items, with internal consistency reliability of 0.94.

\section{Study Procedure}

Students enrolled in the three graduate marketing courses were emailed an invitation to take part in the study by completing a survey created in Qualtrics. The email detailed the purpose of the research and sought their participation in both the study and the survey that followed the project. Students were repeatedly assured of the anonymity of their responses, and effort was made in letting them know that their feedback had no bearing on their overall grade determination. The data was collected after completion of both courses (at the end of two semesters) to solicit honest responses. Students were told the primary purpose of the survey-based feedback on the "Real Company Project" was to promote and strengthen future course content and offerings. As a token of appreciation, students who completed the survey were entered into a random drawing for a chance to win a \$25 iTunes gift card. Besides the first email message, two reminder emails were sent to students, with each request sent a week apart.

Journal of the Scholarship of Teaching and Learning, Vol. 18, No. 2, June 2018.

josotl.indiana.edu 


\section{Results}

Participants rated their agreement with each item on a scale from Strongly Disagree (1) to Strongly Agree (5), with Neither Agree nor Disagree (3) as the midpoint. One-sample t-test results revealed the mean rating for each item was significantly higher than the midpoint of "Neither Agree or Disagree” ( $<$.01). Across the 19 items, five had mean ratings less than four, with the rest having mean ratings greater than four. Table 1 shows the mean and standard deviation for each item.

The Student Motivation to Learn scale resulted in a mean score of 4.32. Most students agreed or strongly agreed that the project improved engagement with the course content (82.4\%) and made discussions in class more enjoyable (93.9\%). There was widespread consensus in recognizing the project was well worth the time spent on it (93.8\%).

The Project as a Learning Device scale received the highest mean score $(M=4.45)$. Ninetyseven percent of students agreed or strongly agreed with the use of a "Real Life Project" as a learning method. They said the project made the subject matter realistic, integrated and illustrated concepts in the course better. Also, most students pointed out the project helped them remember the course material better $(90.1 \%)$.

The seven items comprising the Skills and Personal Benefits scale resulted in a mean score of 3.98. There was an agreement in recognizing the project helped develop teamwork and report preparation skills (75.8\% and 81.8\%, respectively). Responses varied in agreement that the project improved their secondary data search skill set (understanding of how to get information from the library and online databases or websites), and their skill in conducting a SWOT analysis, with $54.5 \%$ and $75.8 \%$, respectively, agreeing or strongly agreeing. However, most students agreed or strongly agreed that their understanding of how to write a business report of findings improved (87.9\%). Students had the most substantial agreement that they advanced in their knowledge of how to analyze the overall dynamics in a product category and how to analyze the competition (93.8\% and $90.1 \%$, respectively).

The final scale was the Overall 'Real Company Project' Assessment consisting of five items resulting in a mean score of 4.28. Most students said the project made the overall course more engaging and that it provided them with the confidence and ability to solve a real-world problem (97\% and 87.9\%, respectively). Almost three-fourths (72.7\%) of the respondents agreed or strongly agreed with the statement that the project would improve their job performance. Overall, students agreed or strongly agreed the project was and would be helpful in other business courses (93.9\%) and recommended that the project continues as a course requirement (97.0\%).

Table 2 and 3 provides the means, standard deviation for each item for each semester. Table 4 provides a comparison of means and standard deviation for each course and also offer t-value and $\mathrm{p}-$ values.

\section{Table 1 - “Real Company Project” Questionnaire Results}

\begin{tabular}{|l|l|l|}
\hline Item & M & SD \\
\hline Student Motivation to Learn & & \\
\hline This project enhanced my engagement with the course content. & 4.24 & 1.06 \\
\hline This project made discussions in class more enjoyable. & 4.30 & 0.81 \\
\hline This project was worth the time spent on it. & 4.34 & 0.83 \\
\hline Project as Learning Device & & \\
\hline
\end{tabular}

Journal of the Scholarship of Teaching and Learning, Vol. 18, No. 2, June 2018. josotl.indiana.edu 


\begin{tabular}{|l|c|c|}
\hline This project made the subject matter realistic. & 4.64 & 0.78 \\
\hline This project integrated concepts in the course. & 4.42 & 0.79 \\
\hline This project illustrated concepts in the course. & 4.33 & 0.78 \\
\hline This project will help me remember the material better. & 4.42 & 0.87 \\
\hline Skills and Personal Benefits & & \\
\hline This project helped me develop my teamwork skills. & 3.87 & 0.87 \\
\hline This project helped my report preparation skills. & 3.97 & 0.81 \\
\hline $\begin{array}{l}\text { My understanding of how to obtain information from the library and online } \\
\text { databases or websites improved. }\end{array}$ & 3.55 & 0.91 \\
\hline $\begin{array}{l}\text { My understanding of how to write a business report of my findings } \\
\text { improved. }\end{array}$ & 4.03 & 0.73 \\
\hline My understanding of how to conduct a SWOT analysis improved. & 3.97 & 0.95 \\
\hline $\begin{array}{l}\text { My understanding of how to analyze the overall dynamics in a product } \\
\text { category improved. }\end{array}$ & 4.31 & 0.69 \\
\hline $\begin{array}{l}\text { My understanding of how to analyze the competition in a category } \\
\text { improved. }\end{array}$ & 4.19 & 0.78 \\
\hline Overall 'Real Company Project’ Assessment & & \\
\hline This project made the overall course more engaging. & 4.58 & 0.79 \\
\hline $\begin{array}{l}\text { This project provided me with the confidence and ability to solve the real- } \\
\text { world issue. }\end{array}$ & 4.21 & 0.93 \\
\hline This project was and will enhance my job performance. & 3.97 & 0.98 \\
\hline This project was and will be helpful in my other business courses. & 4.18 & 0.77 \\
\hline I would recommend that this course continues to require this project. & 4.48 & 0.80 \\
\hline
\end{tabular}

Table 2 - 1st Semester Courses - New Product Development/Customer Centric Innovation

\begin{tabular}{|l|c|c|}
\hline Item & M & SD \\
\hline Student Motivation to Learn & & \\
\hline This project enhanced my engagement with the course content. & 4.00 & 1.41 \\
\hline This project made discussions in class more enjoyable. & 4.25 & 0.46 \\
\hline This project was worth the time spent on it. & 4.29 & 0.49 \\
\hline Project as Learning Device & & \\
\hline This project made the subject matter realistic. & 4.86 & 0.38 \\
\hline This project integrated concepts in the course. & 4.57 & 0.54 \\
\hline This project illustrated concepts in the course. & 4.57 & 0.54 \\
\hline This project will help me remember the material better. & 4.43 & 0.54 \\
\hline Skills and Personal Benefits & & \\
\hline This project helped me develop my teamwork skills. & 4.00 & 0.58 \\
\hline This project helped my report preparation skills. & 3.86 & 0.38 \\
\hline $\begin{array}{l}\text { My understanding of how to obtain information from the library and online } \\
\text { databases or websites improved. }\end{array}$ & 3.57 & 0.54 \\
\hline $\begin{array}{l}\text { My understanding of how to write a business report of my findings } \\
\text { improved. }\end{array}$ & 4.29 & 0.49 \\
\hline My understanding of how to conduct a SWOT analysis improved. & 3.57 & 0.54 \\
\hline
\end{tabular}




\begin{tabular}{|l|c|c|}
\hline $\begin{array}{l}\text { My understanding of how to analyze the overall dynamics in a product } \\
\text { category improved. }\end{array}$ & 4.57 & 0.54 \\
\hline $\begin{array}{l}\text { My understanding of how to analyze the competition in a category } \\
\text { improved. }\end{array}$ & 4.14 & 0.38 \\
\hline Overall 'Real Company Project' Assessment & & \\
\hline This project made the overall course more engaging. & 4.86 & 0.38 \\
\hline $\begin{array}{l}\text { This project provided me with the confidence and ability to solve the real- } \\
\text { world issue. }\end{array}$ & 4.29 & 0.49 \\
\hline This project was and will enhance my job performance. & 4.14 & 0.38 \\
\hline This project was and will be helpful in my other business courses. & 4.14 & 0.38 \\
\hline I would recommend that this course continues to require this project. & 4.71 & 0.49 \\
\hline
\end{tabular}

Table 3 - 2nd Semester Course - Contemporary Issues in International Marketing

\begin{tabular}{|l|l|l|}
\hline Item & M & SD \\
\hline Student Motivation to Learn & & \\
\hline This project enhanced my engagement with the course content. & 4.33 & 0.96 \\
\hline This project made discussions in class more enjoyable. & 4.32 & 0.90 \\
\hline This project was worth the time spent on it. & 4.33 & 0.92 \\
\hline Project as Learning Device & & \\
\hline This project made the subject matter realistic. & 4.56 & 0.87 \\
\hline This project integrated concepts in the course. & 4.40 & 0.87 \\
\hline This project illustrated concepts in the course. & 4.28 & 0.84 \\
\hline This project will help me remember the material better. & 4.48 & 0.92 \\
\hline Skills and Personal Benefits & & \\
\hline This project helped me develop my teamwork skills. & 3.83 & 0.96 \\
\hline This project helped my report preparation skills. & 4.00 & 0.91 \\
\hline $\begin{array}{l}\text { My understanding of how to obtain information from the library and online } \\
\text { databases or websites improved. }\end{array}$ & 3.52 & 1.01 \\
\hline $\begin{array}{l}\text { My understanding of how to write a business report of my findings } \\
\text { improved. }\end{array}$ & 3.96 & 0.79 \\
\hline My understanding of how to conduct a SWOT analysis improved. & 4.04 & 1.02 \\
\hline $\begin{array}{l}\text { My understanding of how to analyze the overall dynamics in a product } \\
\text { category improved. }\end{array}$ & 4.21 & 0.72 \\
\hline $\begin{array}{l}\text { My understanding of how to analyze the competition in ategory } \\
\text { improved. }\end{array}$ & 4.17 & 0.87 \\
\hline $\begin{array}{l}\text { Overall 'Real Company Project' Assessment } \\
\text { This project made the overall course more engaging. }\end{array}$ & 4.48 & 0.87 \\
\hline $\begin{array}{l}\text { This project provided me with the confidence and ability to solve the real- } \\
\text { world issue. }\end{array}$ & 4.20 & 1.04 \\
\hline This project was and will enhance my job performance. & 3.92 & 1.12 \\
\hline This project was and will be helpful in my other business courses. & 4.20 & 0.87 \\
\hline I would recommend that this course continues to require this project. & 0.87 \\
\hline
\end{tabular}


Table 4 - Comparison of 1st and 2nd Semester Courses

\begin{tabular}{|c|c|c|c|c|c|c|}
\hline \multirow[t]{2}{*}{ Item } & \multicolumn{2}{|c|}{$\begin{array}{l}\text { 1st } \\
\text { Semester } \\
\text { Courses }\end{array}$} & \multicolumn{2}{|c|}{$\begin{array}{l}\text { 2nd } \\
\text { Semester } \\
\text { Course }\end{array}$} & \multirow[t]{2}{*}{$\begin{array}{l}\text { t- } \\
\text { value }\end{array}$} & \multirow[t]{2}{*}{$\mathrm{p}-$} \\
\hline & $\mathrm{M}$ & SD & $\mathrm{M}$ & SD & & \\
\hline \multicolumn{7}{|l|}{ Student Motivation to Learn } \\
\hline $\begin{array}{l}\text { This project enhanced my engagement with the } \\
\text { course content. }\end{array}$ & 4.00 & 1.41 & 4.33 & .96 & -.752 & .458 \\
\hline $\begin{array}{l}\text { This project made discussions in class more } \\
\text { enjoyable. }\end{array}$ & 4.25 & .46 & 4.32 & .90 & -.210 & .835 \\
\hline This project was worth the time spent on it. & 4.29 & .49 & 4.33 & .92 & -.131 & .897 \\
\hline \multicolumn{7}{|l|}{ Project as Learning Device } \\
\hline This project made the subject matter realistic. & 4.86 & .38 & 4.56 & .87 & .873 & .390 \\
\hline This project integrated concepts in the course. & 4.57 & .53 & 4.40 & .87 & .495 & .625 \\
\hline This project illustrated concepts in the course. & 4.57 & .53 & 4.28 & .84 & .862 & .396 \\
\hline $\begin{array}{l}\text { This project will help me remember the material } \\
\text { better. }\end{array}$ & 4.43 & .53 & 4.48 & .92 & -.141 & .889 \\
\hline \multicolumn{7}{|l|}{ Skills and Personal Benefits } \\
\hline $\begin{array}{l}\text { This project helped me develop my teamwork } \\
\text { skills. }\end{array}$ & 4.00 & .58 & 3.83 & .96 & .433 & .669 \\
\hline This project helped my report preparation skills. & 3.86 & .38 & 4.00 & .91 & -.401 & .692 \\
\hline $\begin{array}{l}\text { My understanding of how to obtain information } \\
\text { from the library and online databases or websites } \\
\text { improved. }\end{array}$ & 3.57 & .53 & 3.52 & 1.00 & .129 & .898 \\
\hline $\begin{array}{l}\text { My understanding of how to write a business } \\
\text { report of my findings improved. }\end{array}$ & 4.29 & .49 & 3.96 & .79 & 1.031 & .311 \\
\hline $\begin{array}{l}\text { My understanding of how to conduct a SWOT } \\
\text { analysis improved. }\end{array}$ & 3.57 & .53 & 4.04 & 1.02 & 1.162 & .254 \\
\hline $\begin{array}{l}\text { My understanding of how to analyze the overall } \\
\text { dynamics in a product category improved. }\end{array}$ & 4.57 & .53 & 4.21 & .72 & 1.231 & .228 \\
\hline $\begin{array}{l}\text { My understanding of how to analyze the } \\
\text { competition in a category improved. }\end{array}$ & 4.14 & .38 & 4.17 & .87 & -.070 & .945 \\
\hline \multicolumn{7}{|l|}{ Overall ‘Real Company Project’ Assessment } \\
\hline $\begin{array}{l}\text { This project made the overall course more } \\
\text { engaging. }\end{array}$ & 4.86 & .38 & 4.48 & .87 & 1.105 & .278 \\
\hline $\begin{array}{l}\text { This project provided me with the confidence and } \\
\text { ability to solve the real-world issue. }\end{array}$ & 4.29 & .49 & 4.20 & 1.04 & .210 & .835 \\
\hline $\begin{array}{l}\text { This project was and will enhance my job } \\
\text { performance. }\end{array}$ & 4.14 & .38 & 3.92 & 1.12 & .841 & .407 \\
\hline $\begin{array}{l}\text { This project was and will be helpful in my other } \\
\text { business courses. }\end{array}$ & 4.14 & .38 & 4.20 & .87 & -.169 & .867 \\
\hline $\begin{array}{l}\text { I would recommend that this course continue to } \\
\text { require this project. }\end{array}$ & \begin{tabular}{|l|l}
4.71 \\
\end{tabular} & .49 & 4.40 & .87 & .913 & .368 \\
\hline
\end{tabular}

Journal of the Scholarship of Teaching and Learning, Vol. 18, No. 2, June 2018. 


\section{Student Motivation to Learn}

This section of the survey involved three questions designed to ascertain the student's motivation to learn. The first question "This project enhanced my engagement with the course content" resulted in a mean rating of 4 for the $1^{\text {st }}$ semester and 4.33 for the $2^{\text {nd }}$ semester. The second question “This project made discussions in class more enjoyable," achieved a mean rating of 4.25 in the $1^{\text {st }}$ semester and 4.32 in the $2^{\text {nd }}$ semester. The third question in this section, "This project was worth the time spent on it," resulted in a mean rating of 4.29 in the $1^{\text {st }}$ semester and $4.332^{\text {nd }}$ semester. The overall comparison shows the mean values from the $1^{\text {st }}$ semester to the $2^{\text {nd }}$ semester increased for all questions in this section.

\section{Project as Learning Device}

The next four questions on the survey were designed to measure student perceptions of the realworld project as a learning device. Student responses varied considerably among the four questions. "This project made the subject matter realistic" received a mean rating of 4.86 and 4.56 from the $1^{\text {st }}$ and $2^{\text {nd }}$ semester respectively. The mean rating for "This project integrated concepts in the course" were 4.57 for $1^{\text {st }}$ semester and 4.40 for $2^{\text {nd }}$ semester. "This project illustrated concepts in the course" achieved a mean rating of 4.57 in the $1^{\text {st }}$ semester and 4.28 in the $2^{\text {nd }}$ semester. "This project will help me remember the material better" resulted in a mean rating of 4.43 in the $1^{\text {st }}$ semester and 4.48 in the $2^{\text {nd }}$ semester. The overall comparison indicates the mean value for only one item increased between the first and second semester while means for the remaining three items decreased. We believe the declining means for the realistic subject matter, integrating course concepts, and illustrating concepts could well be a function of student fatigue. The fatigue could be because the novelty of the project wore off by the $2^{\text {nd }}$ semester. The repetitive reminders by the instructor to think holistically and to incorporate and integrate elements of all previous coursework led to a high mean value in the first semester but was not perceived as yielding incremental value by the end of the second semester.

\section{Skills and Personal Benefits}

The seven items comprising the Skills and Personal Benefits scale resulted in a mean score increasing for three items from the $1^{\text {st }}$ to $2^{\text {nd }}$ semesters while scores for four items decreased. Respondents pointed out that their report preparation skills, conducting SWOT analysis and analyzing competition skills were increased between the two semesters. Teamwork, getting information from online and library databases, reporting the findings and analyzing the overall dynamics in a product category decreased from one to the other semester. The overall comparison did not show any particular characteristic.

\section{Overall 'Real Company Project' Assessment}

The final scale was Overall 'Real Company Project' Assessment and consisted of five items. The project made the overall course more engaging and provided me with the confidence and ability to solve real-world issues saw a decrease in mean scores from $1^{\text {st }}$ to $2^{\text {nd }}$ semester. Similarly, "this project was and will enhance my job performance" and "I would recommend that this course continues to require this project” also saw a decrease in mean values from $1^{\text {st }}$ to $2^{\text {nd }}$ semester.

Journal of the Scholarship of Teaching and Learning, Vol. 18, No. 2, June 2018. josotl.indiana.edu 
However, "this project was and will be helpful in my other business courses" saw an increase. A comparison of the same is shown in Table 4.

\section{Discussion}

The data and the analysis in the preceding table show that students have a positive perception of the learning associated with real-company projects. This research study replicates and confirms the findings of earlier researchers examining student perceptions of experiential learning.

The results of this project conform to the findings of Benigni, Cheng, and Cameron (2003) who found that client involvement led to more active course outcomes. Question: Most students agreed or strongly agreed to "this project improved my engagement with the course content" (82.4\%); Question: “This project made discussions in class more enjoyable” (93.9\%); Question: "This project was worth the time spent on it." Overwhelmingly students agreed or strongly agreed the project was worth the time spent on it (93.8\%); Question: "This project made the overall course more engaging” Most students said the project made the overall course more engaging (97\%).

Ninety-seven percent of students agreed or strongly agreed "the project made the subject matter realistic" and "This project integrated and illustrated concepts in the course"; and most students articulated the experiential project helped them retain the course material better (90.1\%). In a research study conducted by de los Santos and Jensen (1985), it was found that if the course content with a client-based project seems more like what would be seen in the real-world, students are more interested in learning.

When students were asked to comment on "This project helped my report preparation skills" there was an agreement of $81.8 \%$. Also, most students agreed or strongly agreed that their "understanding of how to write a business report of findings improved" (87.9\%). Students also mentioned, "This project helped me develop my teamwork skills" (75.8\%). Both these student perceptions support the research done by Wickliff (1997) in which a survey of alumni with two to seven years of postgraduate work experience suggested the alumni felt that client-based projects helped them to develop reporting, research, problem analysis, and small group collaboration skills.

Further, there was consistency in the findings associated with student's involvement/ interest in the project if they perceived the same as being relevant to their careers. Razzouk, Seitz, \& Rizkallah (2003) study points out that students interests in a project increase if they perceive it as being relevant to their careers. When students in this study were asked the same question - "This project was and will enhance my job performance,” they responded with $72.7 \%$ agreement.

\section{Conclusions}

The results of this study explore the use of experiential projects across curricula in graduate marketing courses is consistent with the extent literature in business education. The study confirms that experiential learning improves student's learning and the ability to apply concepts holistically to solution-driven decisions as needed by marketing managers. Students gain the much-needed practical experience necessary to "hit the road running" to succeed in their jobs. This is instrumental in closing the gap between a theoretical grasp of the content area and the application of the same in a real-world context. Further, there are significant managerial/practical implications of collaborating with student groups. The key benefits include a fresh perspective on a business problem/situation, a low-cost alternative to addressing a business concern, early identification of potential hires, and informing academia of skills/competency needs.

Journal of the Scholarship of Teaching and Learning, Vol. 18, No. 2, June 2018.

josotl.indiana.edu 
Incorporating experiential learning into the curriculum also has the tangential benefit of fulfilling the current accreditation requirements. AACSB accreditation criteria articulate the need for innovation in teaching courses in a manner that engages businesses, and the communities served. Experiential projects that involve local businesses have the dual benefit of providing local enterprises with an outsider's perspective while giving the student body with compelling realworld experience. While this study points to the efficacy of experiential learning, it must be recognized that this study over two courses has not been examined thoroughly and bears replication across a divergent student and institutional context. The sample size was limited and as stated the study was limited to a single institution in the Caribbean. Further, future researchers would be well served in isolating the experimental effect by incorporating some variety to address the issue of student fatigue. Collaborating with colleagues across the curriculum can enhance the exploration of this topic and minimize student fatigue.

This paper adds to the existing wealth of knowledge on the value of experiential learning activities in business education, in general, and graduate marketing courses in particular. Specifically, the study explores the inclusion of an integrative experiential learning experience over multiple courses. The study confirms the positive contributions to student learning at undergraduate level using experiential learning projects is similarly perceived by these graduate students, offering the opportunity for continued research in this area. The conclusions of this study and the analysis of empirical data related to 'student motivation to learn', students perceptions of 'experiential learning projects as a learning device', 'skills and personal benefits' to students, and 'overall real company project assessment' by the students should encourage many faculty members teaching graduate marketing courses to consider the use of this method. Based on these results, adding an experiential learning project across the curriculum will improve student learning and satisfaction, as well as better prepare students for the 'world of work' to apply the conceptual knowledge gained in their graduate marketing courses to real-world situations

Experiential projects provide students an excellent opportunity to learn by doing. However, these experiential projects may not be right for every course or instructor. Like Fitch (2011) said, assumptions cannot be made about the value of experiential projects. He suggested that learning activities need to be carefully structured to link academic learning and professional development.

\section{References}

Benigni, V. Cheng, I. H. and Cameron, G. T. (2004). The role of clients in the public relations campaigns course. Journalism \& Mass Communication Educator, 59(3): 259-277.

Bobbitt, L. M. Inks, S. A. Kemp, K. J. and Mayo, D. T. (2000). Integrating marketing courses to enhance team-based experiential learning. Journal of Marketing Education, 22(1): 15-24.

Bridges, E. (1999). Experiential learning and customer needs in the undergraduate marketing research course. Journal of Marketing Education, 21(1): 51-59.

Camarero, C. Rodríguez, J. and San José, R. (2010). A comparison of the learning effectiveness of live cases and classroom projects. The International Journal of Management Education, 8(3): 83-94.

Cateora, P. Graham, J. and Mary, G. (2012). International Marketing, 16/e, McGraw-Hill.

Journal of the Scholarship of Teaching and Learning, Vol. 18, No. 2, June 2018.

josotl.indiana.edu 
Civi, E. and Persinger, E. S. (2011). Marketing plan competition for experiential learning. American Journal of Business Education, 4(12): 51-60

Craciun, G. and Corrigan, H. B. (2010). An integrative experiential learning project in the undergraduate branding course: Creating a marketing department brochure. Journal of Marketing Education, 32(2): 116-127.

Darian, J. C. and Coopersmith, L. (2001). Integrated marketing and operations team projects: Learning the importance of cross-functional cooperation. Journal of Marketing Education, 23(2): 128-135.

de los Santos, G. and Jensen, T. D. (1985). Client-sponsored projects: Bridging the gap between theory and practice. Journal of Marketing Education, 7(2): 45-50.

Drafke, M. W. Schoenbachler, D. D. and Gordon, G. L. (1996). Active and passive teaching methodologies: Student outcomes over a semester course. Marketing Education Review, 6(1): 917.

Elam, E. L. R. and Spotts, H. E. (2004). Achieving marketing curriculum integration: A live case study approach. Journal of Marketing Education, 26(1): 50-65.

Field, A. (2013). Exploratory factor analysis. In M. Carmichael (Ed.), Discovering Statistics Using IBM SPSS Statistics (665-719). Thousand Oaks, California: Sage Publications Inc.

Fitch, K. (2011). Developing professionals: Student experiences of a real-client project. Higher Education Research \& Development, 30(4): 491-503.

Frontczak, N. T. and Kelley, C. A. (2000). The editor's corner. Journal of Marketing Education, 22(1): 3-4.

Sanders, G. L. (2013). Developing new products, and services, Washington, D.C.: Flat World Knowledge, Inc.

Gentry, J. W. (1990). What is experiential learning? In J.W. Gentry (Ed.), Guide to Business Gaming and Experiential Learning (9-20). London: Nichols/GP Publishing.

Graeff, T. R. (1997). Bringing reflective learning to the marketing research course: A cooperative learning project using intergroup critique. Journal of Marketing Education, 19(1): 53-64.

Gremler, D. D. Hoffman, K. D. Keaveney, S. M. and Wright, L. K. (2000). Experiential learning exercises in services marketing courses. Journal of Marketing Education, 22(1): 35-44.

Gruca, T. S. (2000). The IEM movie box office market: Integrating marketing and finance using electronic markets. Journal of Marketing Education, 22(1): 5-14. 
Hagan, L. M. (2012). Fostering experiential learning and service through client projects in graduate business courses offered online. American Journal of Business Education, 5(5): 623-632.

Hamer, L. O. (2000). The additive effects of semistructured classroom activities on student learning: An application of classroom-based experiential learning techniques. Journal of Marketing Education, 22(1): 25-34.

Hart, L. K. and Mrad, S. B. (2013). Student-led consulting projects succeed as an experiential learning tool for MBA marketing strategy. Business Education Innovation Journal, 5(2): 75-85.

Humphreys, M. A. (1981). Client-sponsored projects in a marketing research course. Journal of Marketing Education, 3(2): 7-12.

Cagan, J. and Vogel, C.M. (2012). Creating Breakthrough Products, Upper Saddle River, New Jersey: Pearson.

Keeton, M. T. and Tate, P. J. (1978). Learning by experience -what, why, how. San Francisco: Jossey- Bass.

Kennedy, E. J. Lawton, L. and Walker, E. (2001). The case for using live cases: Shifting the paradigm in marketing education. Journal of Marketing Education, 23(2): 145-151.

Kolb, D. A. (1984). Experiential learning: Experience as a source of learning and development. Englewood Cliffs, N.J: Prentice-Hall.

Kunkel, S. W. (2002). Consultant learning: A model for student-directed learning in management education. Journal of Management Education, 26(2): 121-138.

Maskulka, T. A. Stout, D. E. and Massad, V. J. (2011). Using and assessing an experiential learning project in a retail marketing course. Journal of Instruction Pedagogies, 6: 1-20.

McCarthy, M. (2010). Experiential learning theory: From theory to practice. Journal of Business \& Economics Research, 8(5): 131-139.

Munoz, C. and Huser, A. (2008). Experiential and cooperative learning: Using a situation analysis project in principles of marketing. Journal of Education for Business, 83(4): 214-220.

O'Hara, B. S. and Shaffer, T. R. (1995). Details and student perceptions of an experiential program for personal selling and purchasing classes. Journal of Marketing Education, 17(1): 41-49.

Parsons, A. L. and Lepkowska-White, E. (2009). Group projects using clients versus not using clients: Do students perceive any differences? Journal of Marketing Education, 31(2): 154-159.

Petkus, E. (2000). A theoretical and practical framework for service-learning in marketing: Kolb’s experiential learning cycle. Journal of Marketing Education, 22(1): 64-70. 
Razzouk, N. Y. Seitz, V. and Rizkallah, E. (2003). Learning by doing: Using experiential projects in the undergraduate marketing strategy course. Marketing Education Review, 13(2): 35-42.

Richardson, N. and Raveed, S. (1980). A live-case program for teaching marketing research. Journal of Marketing Education, 2(1): 38-49.

Roth, K. J. and Smith, C. (2009). Live-case analysis: Pedagogical problems and prospects in management education. American Journal of Business Education, 2(9): 59-66.

Specht, P. H. (1985). Experiential learning-based vs. lecture-based discussion: The impact of degree of participation and student characteristics on comprehension and retention. The Journal of Business Education, 60(7): 283-287.

Warren, J. L. (2012). Does service-learning increase student learning? A meta-analysis. Michigan Journal of Community Service Learning, 18(2): 56-61.

Wickliff, G. A. (1997). Assessing the value of client-based group projects in an introductory technical communication course. Journal of Business and Technical Communication, 11(2): 170191.

Wynd, W. R. (1989). An experiential approach to marketing education. Journal of Marketing Education, 11(2): 64-71. 